\title{
Cost-Effectiveness of Prison System Development - Comparison of the European Countries
}

Elina Kruze

Riga Graduate School of Law

\section{Janis Priede}

University of Latvia
EIS 14/2020

Cost-Effectiveness of Prison System Development Comparison of the European Countries

Submitted 05/2020 Accepted for publication $07 / 2020$

\section{$\Gamma$} Crossef http://dx.doi.org/10.5755/j01.eis.1.14.26384

The possibility to achieve successful resocialization of former prisoners back into society is an ongoing public debate, making it challenging for policymakers to implement prisoner rehabilitation programs capable of maintaining the public safety while allocating public funds in the most efficient way. The main aim of this study is to examine what is necessary for an investment in prison system development to be justified. The hypothesis of this study suggests that such investment can be cost-effective by reducing crime and recidivism rates in the long term by ensuring proper rehabilitation of prisoners. Accordingly, this research compares various European countries regarding their imprisonment standards and costs in order to conclude which countries operate in the most effective way and what is crucial to obtain a decrease in the reoffending rates. The key results suggest that it is possible to find a correlation between such variables as the imprisonment costs, incarceration rates and the recidivism rates. It is possible to draw parallels between the amount of money countries spend on one prisoner a year and the recidivism rates of such countries, suggesting that the reoffending rates can be reduced by increasing the amount of resources allocated for the improvement of prisoner's lives. Furthermore, such an investment should not only take the form of establishment of a proper environment for successful rehabilitation - prisoners should be provided with education and work possibilities to prepare them for life outside the prison walls. Moreover, the study highlights the need for post-release support mechanisms capable of re-integrating former convicts back into society, since such mechanisms could reduce the likelihood of re-offending.

KEYWORDS: European imprisonment practice; human rights; imprisonment costs; recidivism; rehabilitation.

The possibility of achieving a successful re-socialization of prisoners back into society is an ongoing public debate (Costelloe \& Warner, 2003) making it challenging for policymakers to decide on the implementation of rehabilitation programs which would serve the purpose of maintaining the public safety while allocating public funds in the most efficient way. While decades away application of penalty derived from the desire for revenge and was applied through different means of punishment, policymakers of the $21^{\text {st }}$ century are trying to develop correction measures in a way that would be profitable to both society and the offender.

Despite the fact that the overall imprisonment rate of Europe has experienced a continuous decrease during the last years (Council of Europe, 2018), some European countries remain to have relatively high incarceration rates. Since high prison population creates high costs, the main aim of this research is to conclude what is necessary for the investment in the development of a prison system to be justified. As one of the major causes of the high prison population is the high

\section{Abstract}

Introduction

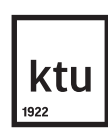

European Integration Studies No. 14 / 2020, pp. 69-79 doi.org/10.5755/j01.eis.1.14.26384 
number of convicts repeatedly incarcerated for property-related offences, the primary purpose of the rehabilitation programs established in the prison facilities of various European countries is to ensure a proper re-socialization of former convicts back into society. Since the reoffending rates of the European countries range from 20\% to 70\% (Council of Europe, 2014), the aim of this research is to come to a conclusion of what the countries with high recidivism rates are lacking. Accordingly, this research is dedicated to the question of what is necessary for an investment in prison system development to be cost-effective in the long term. Hypothesis of this study suggests that the investment in prison system development is cost-effective by reducing crime and recidivism rates in the long term if a proper rehabilitation of prisoners is ensured.

This article applies two legal research methods - the doctrinal method and the comparative method. Firstly, it looks at the development of the European system regarding the legal framework of the standard imprisonment rules. Secondly, it compares different punitive systems, finding a correlation between their imprisonment costs and effectiveness in order to determine which countries operate most effectively based on the rate of reoffending. Accordingly, the qualitative research method is used to explain the existing practice and success of three completely different prison systems, namely the practice of Norway, the Netherlands and Latvia, and the quantitative research method is applied to analyze imprisonment conditions and costs, using the regression analysis in order to find out what effect these costs have on incarceration and recidivism rates in the long term.

In order to reach the aim of the research, the tasks of the study are formulated as follows:

1 to review the movement towards the modern European imprisonment practice;

2 to gather data regarding imprisonment conditions and costs in the chosen European countries;

3 to calculate the correlation between the incarceration costs and reoffending rates;

4 to compare different penal systems regarding the prison conditions, costs and the success of prisoner's rehabilitation programs.

The key findings of this research suggest that the investment in prison system development can be cost-effective if a proper rehabilitation of prisoners has been ensured not only during the time of their incarceration but also after release. Since the high prison population can be reduced by achieving a decrease in reoffending rates, it is of crucial importance to establish post-release support mechanisms capable of ensuring proper resocialization of former prisoners back into society. Moreover, acknowledging the wide range of issues faced by ex-prisoners by the time of their release, such as unemployment and lack of education, it would be in the interest of any state to take the appropriate measures to increase employer's willingness to provide former convicts with job possibilities through employer-support mechanisms, possibly leading to decrease of reoffending rates.

European imprisonment practice
High incarceration rates create high costs. Since almost all the European countries have abolished the death penalty, the most applied means of punishment for a crime committed have taken the form of imprisonment. During the $19^{\text {th }}$ century, the concept of a prison in the view of the European countries experienced a radical change, resulting in a prison being described as "a place of personal reform" and "a testing ground for judging readiness for release" (European Prison Rules, 2006). The United Nations Standard Minimum Rules for the Treatment of Prisoners states that the main aim of imprisonment is to protect citizens against crime, at the same time trying to rehabilitate offenders in order to reduce the recidivism rates (UN Standard Minimum Rules for the Treatment of Prisoners, 1957). Accordingly, it is the rehabilitative aim that has recently gained an increasing support in Europe (Meijer, 2017). Whilst a definition of the term "rehabilitation" has not been provided at the European level, it has been used as a synonym for such expres- 
sions as "resocialization" and "reintegration". Although the idea of the means of rehabilitation has been expressed in the domestic law of various European countries, the rehabilitative ideal varies from one country to another (Martufi, 2018). The European Court of Human Rights has provided that the "process" of rehabilitation entails the possibility of prisoners to engage in such activities as education, work and vocational training (Murray v. the Netherlands [GC], 2016, § 101). It is worth mentioning that among with various rules for acommodation, the UN Standard Minimum Rules has been an essential source for the guidance of prison system management regarding such matters as eduaction, treatment of prisoners and after-care matters, setting international standards below which no state's penitentiary system should fall. However, the extent of rights guaranteed to convicts in practice varies between countries (UNESCO, 2018).

When comparing prison systems of different countries to find out which practices are most profitable to society in the long term, it is essential to look at prison conditions and costs, the approaches established to prepare prisoners for life after release and how effective they are based on recidivism rates. In the following part, the incarceration rates, costs and recidivism rates of 27 countries, namely 25 member states of the European Union, the United Kingdom and Norway, are analysed.

Firstly, a country's GDP per capita is compared with the amount of money spent on prisoners a year. GDP per capita has been computed, dividing the annual GDP of a country in the year of 2018 (Statista, 2018) with the population rate in the same year (Statista, 2018), estimated in euros. Costs per one prisoner a year have been computed, firstly finding the number of prisoners in each country in 2018 , dividing the population rate by the incarceration rate of the same year (Statista, 2018) and further dividing the amount of money spent on the prison system a year by the number of prisoners. Since the latest official data of imprisonment costs in European countries has been provided by the Council of Europe in the Annual Penal Statistics report of 2018, annual imprisonment costs have been derived from this report. As stated in the report, costs of imprisonment estimate the budget spent by penal institutions, including health care, costs of security, administration, services, as well as support and rehabilitation programs (Council of Europe, 2018).

Figure 1 draws a trend of correlation between the GDP per capita and the costs per one prisoner, showing that the bigger the GDP, the more a country is spending on its prisoners. The correlation

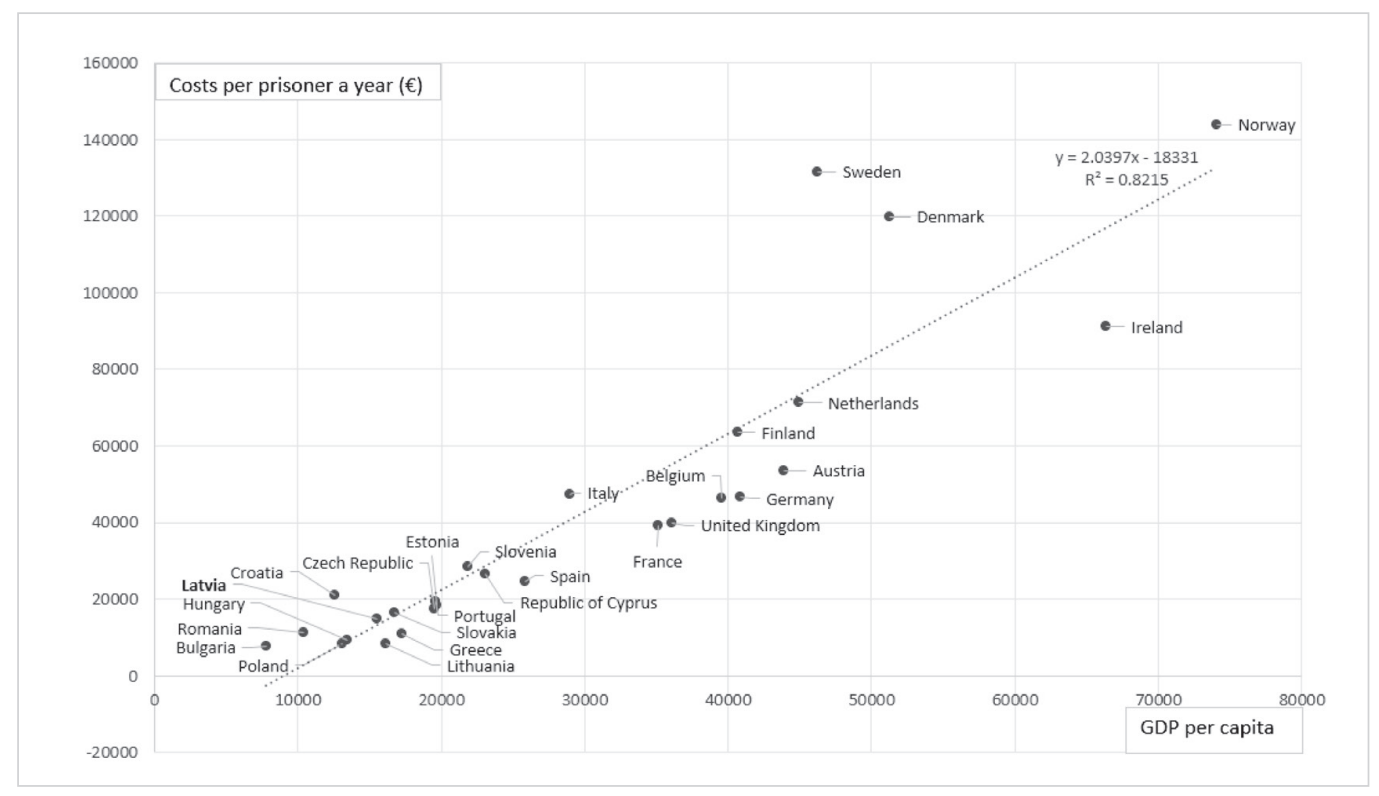

Figure 1

Author's calculations based on data regarding imprisonment costs and GDP per capita of the European countries, in 2018, available on Statista. 
coefficient is 0.91 , which is a strong positive correlation in the amplitude of -1.0 to 1.0 , meaning that for a positive increase in GDP per capita there would most likely be a positive increase in the amount of money spent on one prisoner per year as well. Related determination coefficient $\mathrm{R}^{2}$ of the two variables is 0.82 - in the amplitude of 0.0 to 1.0 it is a strong fit, meaning that $82 \%$ of the variations in the amount of money spent on prisoners by the European countries can be strongly influenced by the change in the GDP.

It can be seen from the graph that three clusters of countries have appeared. Such EU countries as Luxembourg and Malta have been excluded because of the lack of information regarding imprisonment costs. In the first group, which consist of 15 countries, both GDP per capita and money spent on one prisoner per year do not exceed 30000 euro. For most of these countries, both variables are similar. Italy is placed in between two clusters, as its GDP per capita is lower than 30000 euro while it spends almost 50000 euro per year for one imprisonment place. The second cluster consists of 7 countries which spend 40000 euro to 72000 euro per prisoner a year while the GDP per capita of countries vary between 35000 euro and 45000 euro. Although Finland's and Germany's GDP per capita is almost identical (around 40000 euro), Finland spends 63529.62 euro per one imprisonment place, while Germany allocates the amount of 46809.41 euro for the costs of one prisoner a year. The third group consists of 4 countries - Sweden, Denmark, Ireland and Norway. It should be noticed that although the GDP per capita of Sweden is 46238.61 euro which is close to the values of some countries of the second cluster, the amount of money spent on one prison place of the country is almost three times bigger - approximately 131610.72 euro, which is one of the highest numbers spent on one imprisonment place. It is also notable that Denmark, with a GDP per capita of a bit more than 50000 euro, is spending more than twice the amount on one prisoner - almost 119887.60 euro. Another country allocated in the third cluster is Ireland, with the GDP per capita of 66345.83 euro, spending one and a half times more on one prisoner - 91144.31 euro. The fourth member of this cluster is Norway - a country with the highest GDP per capita of approximately 74070.54 euro, spending almost twice the amount for one

Figure 2

Author's calculations based on data regarding incarceration rates and GDP per capita of the European countries, in 2018, available on Statista

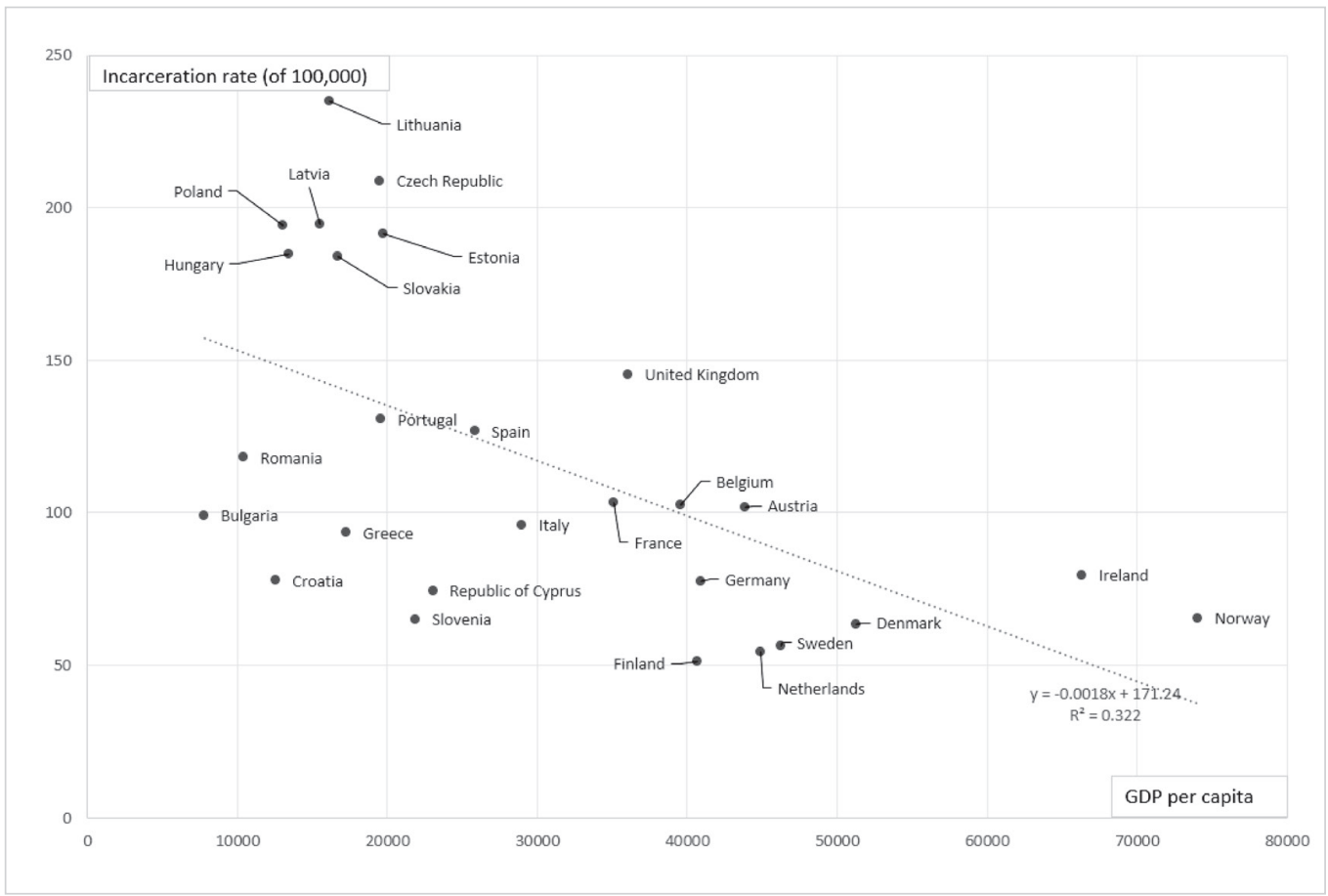


imprisonment place - based on the method of calculations used in this paper and data available, around 143953.08 euro, which is almost twice the amount of the annual GDP per capita.

Secondly, the relation between the GDP per capita and the incarceration rate is examined in order to determine whether the wealthier states have fewer prisoners than the ones with a lower GDP. The correlation between the two variables of GDP per capita and the incarceration rate is -0,57. Although it is not a significant one, the negative correlation means that for an increase in one variable, a decrease in the other one is most likely to appear. In this case, it can be assumed that if the GDP per capita increases, the incarceration rate of a country is most likely to decrease, as a higher GDP per capita means that the standard of living of a country increase. The determination coefficient of the two variables is 0.32 , meaning that in one third of the countries examined the change in the incarceration rates can be predicted due to the change in the GDP. As can be seen from the graph, three identifiable clusters of countries have appeared. The countries creating one cluster in the first graph have now been divided into two groups. The first group of countries consist of Latvia, Lithuania, Estonia, Poland, Czech Republic, Hungary and Slovakia. This cluster of countries has the highest incarceration rate in the European Union - 180 to 240 people out of 100000 citizens are imprisoned. Annual GDP per capita of these countries varies between 12 000 euro and 20000 euro. The second group of countries consists of Portugal, Spain, Romania, Bulgaria, Greece, Italy, Croatia, the Republic of Cyprus with incarceration rate between 70 and 140 people per 100000 citizens, and Slovenia with the lowest incarceration rate of this cluster in this country, only 65 out of 100000 citizens are imprisoned. Although the incarceration rate of these countries is almost two times smaller than the one of the first group, there is no significant difference in GDP per capita - for the second group countries, it varies between 7700 euro and 29 000 euro. An interesting phenomenon is the geographical composition of both groups of countries - since both the unemployment rate (Trading Economics, 2019) and the level of happiness of people (Eurostat, 2019) in the countries of the first and the second cluster do not differ significantly, one may connect the geographical position of both clusters with the differences of incarceration rates because of climate differences. It can be seen that countries of the second cluster are located closer to the equator and have lower incarceration rates. Researches have shown that homeless people have frequently committed crimes punishable by imprisonment in order to spend some time off the streets (Abadi, 2018). Although not the only possible explanation for the difference between both clusters, one of the reasons for a higher imprisonment rate in countries with a colder climate could be the fact that homeless people are more likely to commit a crime to receive shelter for the cold months of the year in places further away from the equator. The third cluster of countries consists of 12 countries, 11 of which have the annual GDP per capita between 35000 euro and nearly 75000 euro. The incarceration rate of these countries varies between 50 to 100 people per 100000 citizens - this group consists of countries that are wealthier than the ones of the other two clusters. As can be seen from the graph, countries with the lowest incarceration rates are Finland, the Netherlands, Sweden, Denmark and Norway. Although included in this group of countries, the United Kingdom has GDP per capita of 36000 euro, at the same time having 145 out of 100000 citizens behind bars. During the last 25 years, the imprisonment rate of the UK has doubled, and the authorities continue increasing the amount spent on prisoners in overcrowded prisons by reallocating funds from rehabilitative programs (Jenkins, 2019).

Finally, figure 3 examines the relation between costs per one prisoner a year and recidivism rate in order to see whether the hypothesis put forward in this paper can be confirmed by comparing EU countries which have provided for such information. Recidivism rate shows the percentage of prisoners who, after being released from prison, return to it after they have committed another crime. 


\section{Figure 3}

Author's calculations based on data regarding costs per prisoner a year and recidivism rates of the European countries, in 2018, derived from CoE reports

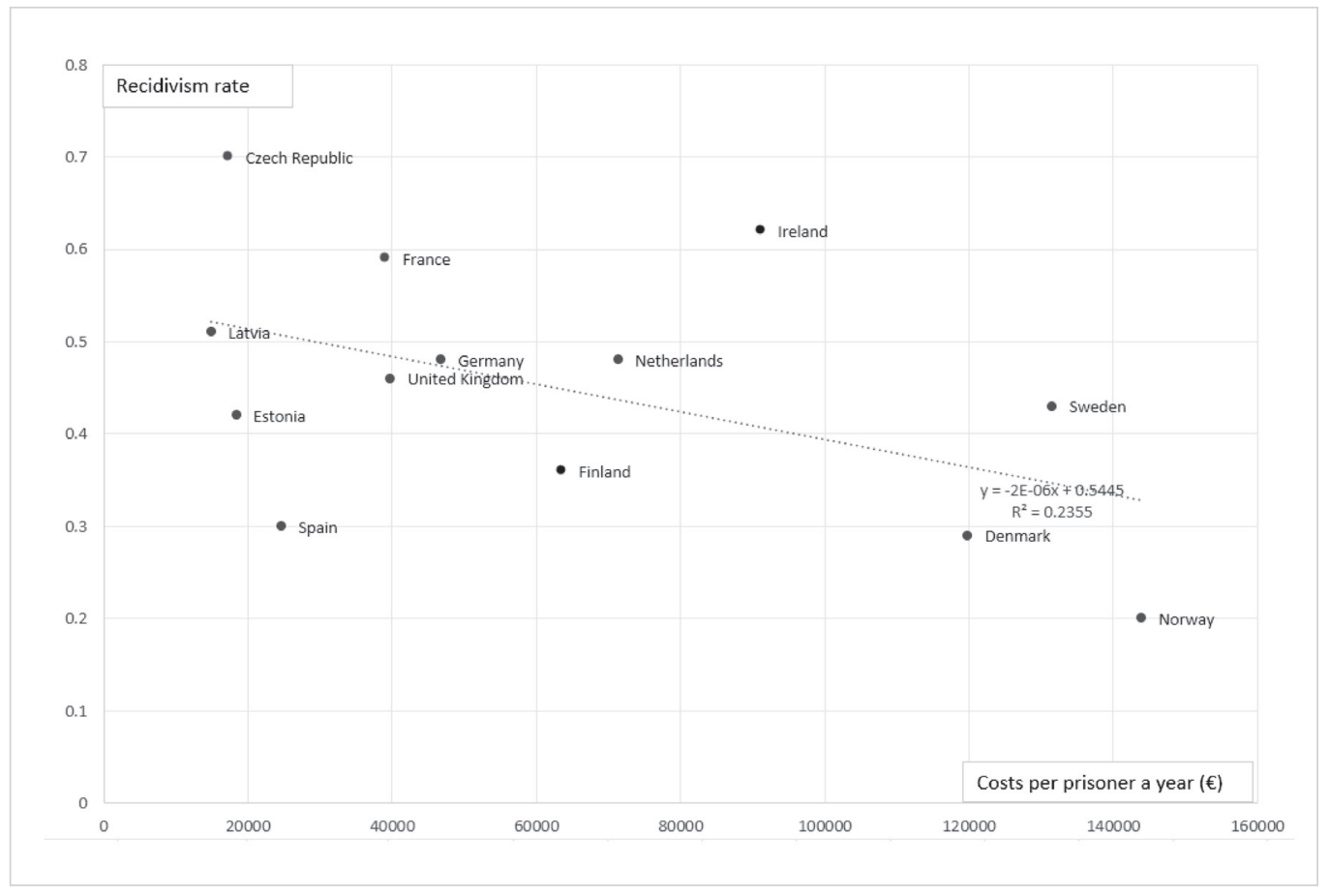

Correlation between the two variables of annual costs per prisoner and recidivism rate is -0.49 , comparing 13 countries which have made the information about reoffending rates available to the public. Determination coefficient of the countries examined is 0.24 . When calculating the correlation of these countries, it should be taken into account that Spain has provided the recidivism rate of 0.3 only for the territory of Catalonia (Capdevila \& Serentill \& Puig \& Pueyo \& Ferrer \& Lopez $\&$ Bou $\&$ Pedro, 2015). Without the recidivism rate of Spain, there is a stronger negative correlation of -0.62 , and the determination coefficient changes to 0.41 . As it can be seen from the graph, five countries - Czech Republic, France, Netherlands, Denmark and Norway - create a negative slope, and the correlation rate of these countries is -0.99 , which is a perfect negative correlation, meaning that there is a high possibility that with an increase in the amount of money spent on prisoners the rate of recidivism is being reduced. Determination coefficient of the five countries is 0.99 , creating an absolute fit and meaning the recidivism rate of these countries is strongly influenced by the changes in the amount of money spent on prisoners. It is worth mentioning that Norway, which firmly believes in restorative justice, aiming to rehabilitate offender, not to punish it (Sterbenz, 2014), has one of the lowest incarceration rates of 65.4 people per 100 000 citizens and the lowest recidivism rate of $20 \%$ in the world. In Norway, the loss of freedom is looked upon as punishment itself, and even the inmates of the high-security prison have a duty to engage in such activities as work, educational and rehabilitative programs, which cost much money but have proved to be cost-effective in the long term, significantly reducing the recidivism rate (Giertsen \& Alnaes \& De Vos \& Jacobsen \& Dietrichson \& Horn, 2019).

Even though reasons for high incarceration rates vary from one country to another, there is a trend of criminalisation of such social problems as substance dependency, poverty and lack of proper education (Heard, 2016). One of the main reasons for high prison population rates is the practice of sentencing a significant number of convicts to serve long imprisonment terms for property-related offences; this kind of practice leads to high prison density, often resulting in various human rights violations due to overcrowded detention facilities. Given that the majority 
of prisoners are going to be released at some time in the future, it is a safety imperative of every society to ensure that detention facilities have the resources necessary for the establishment of proper rehabilitation programs. Although there is no one answer provided to the question of what the most effective rehabilitative approaches of prisoners are and what cost-benefit they bring to taxpayers, it can be assumed that rehabilitative programs can be cost-effective once they reduce the rate of reoffending. Therefore, the imprisonment practice of one country from each cluster is further analysed in order to examine what are the reasons for different rehabilitation practices and their outcomes, namely the ones of Norway, the Netherlands and Latvia.

In the 1980s the prison system in Norway was utterly different than it is nowadays, with the focus on security and having the recidivism rate of $60-70 \%$ (Papendorf, 2006). Ten years later, the Norwegian Correctional Service changed the prison system entirely by the introduction of various reforms, starting to focus more on rehabilitation than punishment and offering different educational programmes and other activities to prison inmates who had previously been locked up in their cells most of the time. Nowadays, there is no overcrowding present in Norwegian prison facilities, and the correctional officers are highly trained to assist convicts through their rehabilitation process. While in most of the countries socio-educational workers and correctional officers are two different professions, the officers of Norwegian prisons are both. Since Norwegians strongly believe in the rehabilitative approach, prison conditions are created in a way that makes a convict's life in both open and closed prisons as similar to the outside world as possible. Moreover, all prisoners are provided with primary and secondary education, additional training in a wide range of different courses, and even with the possibility to enrol in higher education studies. Like nowhere else, Norwegian prisoners have the access to music classes, concerts and theatre, and they are obliged to spend at least one hour a day outside, where they can take part in various sports programs together with prison officers. Although offenders imprisoned have a "duty of activity", they are not ordered to participate in activities against their will - if they refuse to take part, an order to work is an alternative to such activities (Giertsen \& Alnaes \& De Vos \& Jacobsen \& Dietrichson \& Horn, 2019). In general, all prisoners have an opportunity to have a job which they can lose as a punishment for bad behaviour, and sometimes they can even apply for a transfer to another prison which offers a broader range of jobs. By creating a regime under which almost of all the prisoners do take part in education, work and other programmes, the re-offending rate of Norway has significantly decreased to only $20 \%$. Therefore, it can be concluded that the country has established a system which is cost-effective due to its capability to reduce the prison population by successful reintegration of former convicts back into society.

An unusual situation has appeared in the Netherlands - during the last 15 years, the prison population has almost halved, resulting in a shut-down of 29 prison facilities in the last five years (Douw \& van't Hoff, 2019). Having an incarceration rate of 54.4 people out of 100000 citizens, the Netherlands has one of the lowest prison population rates in the world. Even after starting to rent out places in prisons to other countries, it does not have enough prisoners to fill up the remaining 30 prisons (Boztas, 2019). The main reasons for such a situation have been told to be both the declining crime rates and increasing use of imprisonment alternatives, such as financial fines. Dutch government studies on prison capacity have helped the policy-makers to understand that an increase in shorter sentences and alternative sentencing rather than unnecessarily long imprisonment terms is an essential factor in reducing the prison population. Since has not been proved that long imprisonment sentences lead to lower crime rates, the imposition of imprisonment alternatives has proved to be beneficial in some cases. Conditions of prison facilities in the Netherlands are considered up to recommended material standards (Douw \& van't Hoff, 2019). 
As there are no other education possibilities than distance training courses available, and the only activity inmates are obliged to attend is work. Since the current recidivism rate of the Netherlands is $48 \%$, there have been new rehabilitation programs established in order to reduce the probability of reoffending. A non-profit Prison Care organisation has established a program that invites entrepreneurs to prison to allow them to meet inmates in person, providing offenders with an opportunity to work outside prison walls during the day time in order to establish connections with their future employers (Batist, 2019). Out of the 68 ex-prisoners who joined the project before being released, 43 have successfully been reintegrated back into society, having stable employment and a place to live. Since one of the main reasons for reoffending is the unemployment of former convicts, establishment of projects ensuring the re-introduction of prisoners back into the labour market can be cost-effective in the long term, reducing the likelihood of reoffending.

The incarceration rate of Latvia is relatively high - 194 people out of 100000 are imprisoned in the existing nine prison facilities (Ministry of Justice, 2018). Even though new models of resocialization programs have been implemented in the recent years, the rate of recidivism has not decreased; the reduction in the number of people imprisoned is the result of changes in the policy of criminal punishment, not a success of sufficient rehabilitation programs. The inappropriate accommodation conditions leading to overcrowding and violations of human rights is only one of the issues present in Latvian detention facilities. According to the statistics of 2018, one fourth of the prisoners serving their sentences in Latvian prisons have been incarcerated at least for the fourth time for property-related crimes (State Control of the Republic of Latvia, 2019). Latvian Probation Service has stated that one out of five prisoners commits a crime during the first year after being released (Latvian Probation Service, 2017) due to various problems hindering the re-socialization of prisoners. Although in most prisons inmates are offered to attend to employment, educational or vocational programs, having additional access to outdoor yards and gym, there are some prisons where the daily exercise hour outside remain the only activity accessible for inmates, and for the remaining day, prisoners are locked up in their cells (Kamenska \& Pūce \& Laganovska, 2013). There are not enough employment opportunities present - mostly prisoners sew uniforms or practice woodworking, and it has resulted in a situation where demand for jobs exceeds supply. While around half of prisoners are enrolled in educational programs, only one out of four convicts are working in prison; despite the fact that entrepreneurs are willing to expand their businesses by increasing work opportunities for prisoners, the prison infrastructure does not allow for that. Since the most significant part of the prison population in Latvia is created by thieves, robbers and those convicted of drug-related offences (Central Statistical Bureau of Latvia, 2019), it is often the case that 30-year-old convicts sent to prison for committing one of the crimes mentioned above have no basic knowledge and no social skills; for many inmates, prison is the first workplace. Therefore, the lack of work-related education during the time of imprisonment is preventing former prisoners from being successfully re-introduced in the labour market, leading to high recidivism rates. If the recidivism rate of $51 \%$ was reduced to $50 \%$, the number of re-offenders sent back to Latvian prisons would decrease by 37 people; knowing that one prisoner costs approximately 14939.45 euro a year, 552759.65 euro would be saved annually. As most of the offenders are sentenced after committing a property crime, it may be supposed that those 37 people would not have to serve a term of up to 5 years, increasing the amount of money saved to roughly 2.76 million euro. Another important factor which should be considered is the employment - supposing that 37 people would earn the minimum wage of 430 euro, an amount of 15910 euro per month would be earned, outweighing the cost of one prisoner a year. The overall savings could be calculated by adding up the money saved on imprisonment expenses of 37 people with the amount of money they would earn in five years, making a total of roughly 3.72 million euro. Acknowledging how much resources 
would be saved if the recidivism rate was reduced by only $1 \%$ and how important part of the re-socialization process the employment of ex-prisoners is, in a country where employers are highly unwilling to provide offenders with job opportunities (Kupčs \& Zvirbulis, 2019) it would be in the interest of both the society and the authorities to take the appropriate measures in order to increase the entrepreneur's willingness to employ former convicts.

- An establishment of policies oriented on re-socialization of prisoners back into society can be cost-effective if a proper rehabilitation of offenders is ensured not only during the time of imprisonment but also after release, meaning that the hypothesis of the research can be confirmed.

- The decrease in reoffending rates can have a positive impact on incarceration rates, reducing the number of people who return to prison repeatedly. Accordingly, a decrease in the prison population would reduce the annual expenses of providing prisoners with the basic needs, allowing to allocate funds to the improvement of prison facilities and further implementation of rehabilitation programs.

- It is possible to find a correlation between such variables as the imprisonment costs, incarceration rates and the recidivism rates of the European countries. Countries with lower incarceration rates tend to have a higher annual GDP; accordingly, the wealthier the state, the more resources it is willing to allocate to the improvement of convict's lives.

- The correlation between the annual imprisonment costs of a prisoner and the recidivism rate is noteworthy, as the correlation of the money spent on prisoners a year and the reoffending rates of the countries examined is -0.62 ; moreover, the data of five countries create strong negative correlation of -0.99 which, taken together with the determination coefficient of 0.99 suggests that there is a high possibility that the reoffending rates can be reduced by increasing the amount of resources allocated for the improvement of prisoner's lives.

- The qualities offenders have gained during the rehabilitation processes in prisons, such as vocational training and education, should not be wasted by weak post-release support measures. Therefore, it is of crucial importance to establish proper after-release mechanisms which would promote a continuation of the rehabilitation of prisoners by ensuring their capability of living a self-supporting and law-abiding life outside prison walls.

- In order to ensure offender's willingness to change, it is necessary to create the appropriate environment; assuring proper accommodation and non-existence of human rights abuses in the detention facilities is essential for achieving one's correction, not further damage.

- Even if during the imprisonment term offenders have gained all the qualities necessary for living a self-supporting life, former convicts face various difficulties after release. Discrimination, lack of work history, occupational skills and experience in the job-seeking processes are only some of the problems faced by ex-prisoners. Therefore, it is important to take the measures necessary to establish mechanisms helping offenders to find an employee to the greatest extent possible.

- One of the main problems is the lack of stage between imprisonment and freedom. It is of crucial importance to provide prisoners with work-related education during their imprisonment and proper employment after release. Therefore, an establishment of projects ensuring the re-introduction of prisoners back into the labour market can be cost-effective in the long term since one of the main reasons for reoffending is the lack of post-release supporting mechanisms.

- Acknowledging the employer's unwillingness to employ former convicts in Latvia, it would be in the interest of the authorities to establish prisoner employer's support mechanisms through tax reliefs or the introduction of wage subsidies, since such privileges could increase employer's willingness to provide ex-prisoners with job opportunities, possibly leading to decrease of reoffending rates. 
Abadi, M. (2018). Some people get arrested on purpose so they can go to jail - and their reasons range from sad, to nefarious, to political. Business Insider (March). Retrieved March 29, 2020, from https:// www.businessinsider.com/jail-getting-arresteddeliberately-2018-3\#because-jail-is-better-thanlife-on-the-streets-5

Batist, D. (2019). How the dutch are closing their prisons. Retrieved April 5, 2020, from https://www.usnews. com/news/best-countries/articles/2019-05-13/thenetherlands-is-closing-its-prisons

Boztas, S. (2019). Why are there so few prisoners in the Netherlands? The Guardian (December). Retrieved April 2, 2020, from https://www.theguardian.com/ world/2019/dec/12/why-are-there-so-few-prisoners-in-the-netherlands

Central Statistical Bureau of Latvia. (2019). Statistics in Brief 2019. Retrieved May 20, 2020, from https://www.csb.gov.lv/sites/default/files/publication/2019-05/Nr_03_Latvia_Statistics_in\%20 Brief\%202019_\%2819_00\%29_EN.pdf

Costelloe, A. \& Warner, K. (2003). Beyond 'Offending Behaviour': The Wider Perspectives of Adult Education and the European Prison Rules. Retrieved from https:// www.researchgate.net/profile/Anne_Costelloe/ publication/264849423_Beyond_'Offending_Behaviour'_The_Wider_Perspectives_of_Adult_Education_ and_the_European_Prison_Rules/links/575e9e7c08aed884621b5595.pdf

Council of Europe. (2014). Annual Penal Statistics - Recidivism studies. Retrieved March 25, 2020, from https://wp.unil.ch/space/publications/recidivism-studies/

Council of Europe. (2018). Prison Populations. Retrieved March 25, 2020, from http://wp.unil.ch/space/ files/2019/06/FinalReportSPACEl2018_190611-1.pdf

Douw, F. \& van't Hoff. (2019). The Netherlands. Prison Insider. Retrieved March 15 from https://www.prison-insider.com/countryprofile/netherlands-2019

European Prison Rules (2006), part IV (c). Retrieved from https://rm.coe.int/european-prison-rules-97892-871-5982-3/16806ab9ae

Eurostat. (2018). Archive: Quality of life in Europe facts and views - overall life satisfaction. Retrieved March 20, 2020, from https://ec.europa.eu/eurostat/
statistics-explained/index.php?title=Archive:Quality_of_life_in_Europe_-_facts_and_views_-_overall_ life_satisfaction\&oldid $=400088$

Giertsen, H. \& Alnaes, O. \& De Vos, H. \& Jacobsen, M. H. \& Dietrichson, M. O. \& Horn, T. (2019). Norway. Prison Insider. Retrieved March 15 from https:// www.prison-insider.com/countryprofile/prisons-norway2019

Heard, C. (2016). Alternatives to imprisonment in Europe: $A$ handbook of good practice. European Prison Observatory. ISBN 978-88-98688-14-2

Jenkins, S. (2019). Prisons do damage. Is the British government finally waking up to this? The Guardian (April). Retrieved April 1, 2020, from https://www.theguardian.com/commentisfree/2019/apr/06/prisons-damage-british-government-reform-short-sentences

Kamenska, A. \& Pūce, I. \& Laganovska, K. (2013). Prison Conditions in Latvia. European Prison Observatory. Retrieved May 15, 2020, from https://www.crimeandjustice.org.uk/sites/crimeandjustice.org.uk/files/Prison $\% 20$ conditions\%20in\%20Latvia.pdf

Kupčs, E. \& Zvirbulis, G̦. (2019). Study: Former prisoners would like to work, but employers discriminate against them because of the past. Retrieved April 11 2020, from https://www.lsm.lv/raksts/zinas/latvija/ petijums-bijusie-ieslodzitie-gribetu-stradat-tacu-pagatnes-del-darba-deveji-vinus-diskrimine.a313343/

Martufi, A. (2018). The Paths of Offender Rehabilitation and the European Dimension of Punishment: New Challenger for an Old Ideal? Maastricht Journal of European and Comparative Law, 25(6), 672-688. https:// doi.org/10.1177/1023263X18820678

Meijer, S. (2017). Rehabilitation as a Positive Obligation. European Journal of Crime, Criminal Law and Criminal Justice, 25(2), 145-162. https://doi. org/10.1163/15718174-25022110

Ministry of Justice (2018). Latvia. Prison Insider. Retrieved April 10, 2020, from https://www.prison-insider.com/en/countryprofile/lettonie-2018?s=vue-d-ensemble\#vue-d-ensemble

Murray v. the Netherlands [GC], no. 10511/10, 26 April 2016

Papendorf, K. (2006). The Unfinished: Reflections on the Norwegian Prison Movement. Acta Sociologia 49 (2). https://doi.org/10.1177/0001699306064767 
Prison Administration. (2018). Incarceration Statistics. Retrieved March 22, 2020, from http://www. ievp.gov.lv/images/stories/stat/statistika/leslodzijuma_vietu_parvaldes_publicejama_statistika_2018.docx.pdf

State control of the Republic of Latvia. (2019). Effectiveness of state re-socialization measures of convicted persons. Retrieved March 20, 2020, from http://www.lrvk.gov.lv/uploads/reviziju-zinojumi/2018/2.4.1-11_2018/RevZin_ Resoc_28102019.pdf

Statista. (2018). EU member states: total population in 2018 with a forecast for 2050 , by country. Retrieved March 20, 2020, from https://www.statista.com/statistics/253383/total-population-of-the-eu-memberstates-by-country/

Statista. (2018). Gross domestic product (GDP) at current market prices of selected European countries in 2018. Retrieved March 20, 2020, from https:// www.statista.com/statistics/685925/gdp-of-european-countries/
Statista. (2018). Incarceration rate in European Countries in 2018. Retrieved March 20, 2020, from https:// www.statista.com/statistics/957501/incarceration-rate-in-europe/

Sterbenz, C. (2014). Why Norway's prison system is so successful. Business Insider (December). Retrieved April 1, 2020, from https://www.businessinsider. com/why-norways-prison-system-is-so-successful-2014-12

Trading Economics. (2019). Unemployment rate - Europe. Retrieved March 20, 2020, from https://tradingeconomics.com/country-list/unemployment-rate?continent=europe

UNESCO. (2018). Protecting the human rights of prisoners. Retrieved March 27, 2020, from https:// en.unesco.org/courier/2018-4/protecting-human-rights-prisoners

United Nations Standard Minimum Rules for the Treatment of Prisoners (31 July 1957), para 58. Retrieved from https://www.unodc.org/pdf/criminal_justice/ UN_Standard_Minimum_Rules_for_the_Treatment_ of_Prisoners.pdf

\section{KRUZE ELINA}

\section{LL.B in Law and Business}

Institution: Riga Graduate School of Law

\section{Fields of interests}

Human rights law, European Union law, doctrinal analysis.

\section{Address}

Address: Strelnieku street 4k-2, Riga

Phone: +371 27193748

E-mail: eliinakruuze3@gmail.com

\section{PRIEDE JANIS}

Dr. oec. Professor

Institution: University of Latvia

\section{Fields of interests}

Economics, quantitative research, competition, industry.

\section{Address}

Address: Aspazijas bulv. 5, Riga

Phone: +371 67034973

E-mail: janis.priede@lu.lv

\section{About the} authors 